Article

\title{
Chronology of Missoula Flood Deposits at the Coyote Canyon Mammoth Site, Washington State, USA
}

\author{
George V. Last ${ }^{1,2, *}$ and Tammy M. Rittenour ${ }^{3}$ (D) \\ 1 Mid-Columbia Basin Old Natural Education Sciences (MCBONES) Research Center Foundation, \\ Kennewick, WA 99338, USA \\ 2 School of the Environment, Washington State University-Tri-Cities, Richland, WA 99354, USA \\ 3 Department of Geosciences, Utah State University, Logan, UT 84322, USA; tammy.rittenour@usu.edu \\ * Correspondence: gvlast@charter.net; Tel.: +1-509-946-8050
}

check for

updates

Citation: Last, G.V.; Rittenour, T.M.

Chronology of Missoula Flood

Deposits at the Coyote Canyon

Mammoth Site, Washington State,

USA. Quaternary 2021, 4, 20.

https://doi.org/10.3390/quat4030020

Academic Editor: David Bridgland

Received: 27 April 2021

Accepted: 29 June 2021

Published: 6 July 2021

Publisher's Note: MDPI stays neutral with regard to jurisdictional claims in published maps and institutional affiliations.

Copyright: (c) 2021 by the authors. Licensee MDPI, Basel, Switzerland. This article is an open access article distributed under the terms and conditions of the Creative Commons Attribution (CC BY) license (https:// creativecommons.org/licenses/by/ $4.0 /)$.

\begin{abstract}
Late Pleistocene outburst megafloods, mostly from glacial Lake Missoula, hydraulically ponded behind downstream constrictions in the Columbia River in southeastern Washington State, USA. Optically stimulated luminescence (OSL) ages for flood deposits from the Coyote Canyon Mammoth Site, located in a high (315-320 m asl) distal portion of the transient lake, indicate that at least seven floods ponded high enough to inundate the area during the period $20.9 \pm 2.6 \mathrm{ka}$ to $16.3 \pm 2.8 \mathrm{ka}$. This is consistent with a radiocarbon age of about $17.4 \pm 0.2 \mathrm{ka}$ cal BP from the middle of the flood sequence. OSL ages from loess deposits overlying a paleosol at the top of the flood sequence range from $14.0 \pm 2.3 \mathrm{ka}$ to $10.9 \pm 2.0 \mathrm{ka}$, suggesting a hiatus of about 2.3 thousand years. These datasets are consistent with current understanding that multiple late Pleistocene megafloods occurred between $20 \mathrm{ka}$ and $14 \mathrm{ka}$ and that earlier floods produced higher flood stages than later ones. The lack of flood deposits in the Coyote Canyon area younger than 16 ka supports the hypothesis that younger megafloods did not hydraulically pond in the Pasco Basin above about $230 \mathrm{~m}$ asl.
\end{abstract}

Keywords: Missoula floods; Lake Lewis; ice age floods; mammoth; Mammuthus; OSL; geochronology; late Pleistocene

\section{Introduction}

Floodwaters from Late Pleistocene outburst megafloods, mostly from glacial Lake Missoula, hydraulically ponded behind downstream constrictions (such as Wallula Gap), forming a large transient body of water (lasting only weeks) in southeastern Washington State, USA. These hydraulically ponded flood stages inundated much of the Pasco Basin and backflooded its tributary valleys including the Yakima and Walla Walla valleys. This repeatedly formed a transient large body of water has been referred to as Lake Lewis, and sometimes confusedly referred to a "glacial Lake Lewis" (Figure 1). Rhythmically bedded slackwater sediments deposited in the quiet margins and tributary valleys of the hydraulically ponded lakes provide evidence for repeated flood episodes with lengthy time (decades) between each flood episode [1-3]. These floods led to the demise of numerous mammoths and other animals occupying the fertile valleys of southeastern Washington between flood episodes, sweeping their carcasses into the locally quiet waters of Lake Lewis [4]. In fact, most of the mammoth remains discovered in eastern Washington have been found in slackwater flood deposits [5].

Here, we present the stratigraphy associated with seven optically stimulated luminescence (OSL) ages for Missoula-flood rhythmites that entomb Columbian mammoth (Mammuthus columbi) remains and overlying loess deposits from the Coyote Canyon Mammoth Site (CCMS) and another nearby excavation. These data not only provide key constraints on the timing of geologic events at CCMS, but also expand our understanding of the dynamic nature and chronology of Lake Lewis flood stages [6]. 


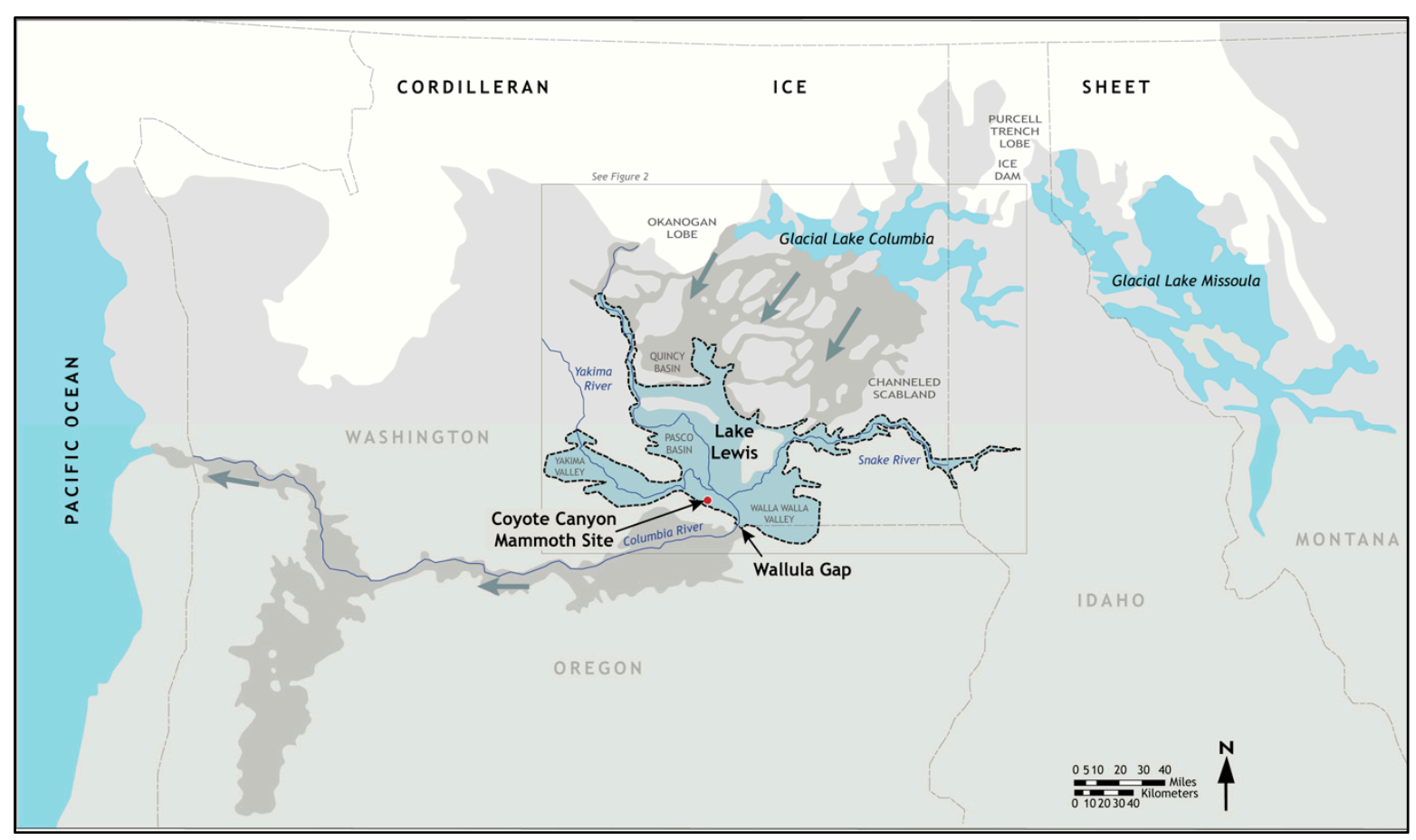

Figure 1. Schematic of the hypothetical extent of hydraulically ponded floodwaters, assuming a static flood stage of $366 \mathrm{~m}$ asl, forming a large transient body of water, referred to as Lake Lewis in Southeastern Washington State (based on a map available from the Ice Age Floods Institute (https:/ / iafi.org/product/ice-age-floods-in-the-pacific-northwest-map/) accessed on 4 April 2021). Darker shading indicates areas impacted by Late Pleistocene outburst megafloods.

Current understanding suggests that dozens (perhaps as many as 100) of late Pleistocene megafloods occurred between 20 and $14 \mathrm{ka}$, with large uncertainties in this age range [2,7-11]. The decreased thickness, grain-size, and erosiveness of younger flood beds, as well as the reduced number of young flood beds at higher altitude, suggests that earlier floods were larger in maximum discharge than later ones [1,2,7,10-15]. Reduced flood magnitude appears to coincide with increased flood frequency (as expected for a self-dumping lake) resulting from late-glacial thinning of the ice dam $[1,2,11,13]$. However, there are limited data on the age of specific flood events and the corresponding flood stages of Lake Lewis.

The maximum elevation of ice-rafted erratics, divide crossings, and loess scarps indicates that the flood stages of some of these transient lakes may have reached an elevation of at least $366 \mathrm{~m}$ asl and perhaps as high as $380 \mathrm{~m}$ asl [11,16]. However, the preponderance of ice-rafted erratics, mammoth remains, and other debris left stranded on the shoreline of Lake Lewis suggests that most of the flood stages reached elevations of only 180-300 m asl [17]. Rhythmites containing Mount St. Helens Set S (MSH-S) tephra are generally restricted to elevations below $230-275 \mathrm{~m}[1,18]$. Thinning and fining of these upper rhythmites suggest the last several (perhaps tens of) floods were smaller and may have been more frequent $[1,18,19]$. Figure 2 illustrates the extent of Lake Lewis at different flood stages [17].

Cosmogenic ${ }^{36} \mathrm{Cl}$-exposure ages have been reported for four erratics located along the southwestern perimeter of Lake Lewis within the Pasco Basin [15] (Figure 3). Three of these erratics are located on the northeastern flank of Rattlesnake Mountain in an area where over 2,100 ice-rafted erratics, sometimes found in clusters and bergmounds have been documented [16]. Located at elevations of 209, 225, and $310 \mathrm{~m}$ asl they yielded ages of $16.2 \pm 1.3 \mathrm{ka}, 16.7 \pm 2.7 \mathrm{ka}$, and $16.9 \pm 3.4 \mathrm{ka}$, respectively (Table 1). The fourth erratic was in a side canyon (Badger Canyon) southeast of the main Lake Lewis body. It was located at an elevation of $268 \mathrm{~m}$ asl and yielded an anomalously old age of $35.6 \pm 1.2 \mathrm{ka}$ (Table 1). The unexpected old age of this erratic is currently unexplained, but is likely due to inheritance. 
An OSL age of $21 \pm 2 \mathrm{ka}$ was reported for the top of a sequence of $\sim 15$ rhythmites located along While Bluffs at an elevation of $\sim 185 \mathrm{~m}$ asl in the central portion of former Lake Lewis, and an OSL age of $12 \pm 2$ ka for the top of a younger sequence of sediments in a paleochannel incised into the rhythmite sequence [15] (Figure 3, Table 1).

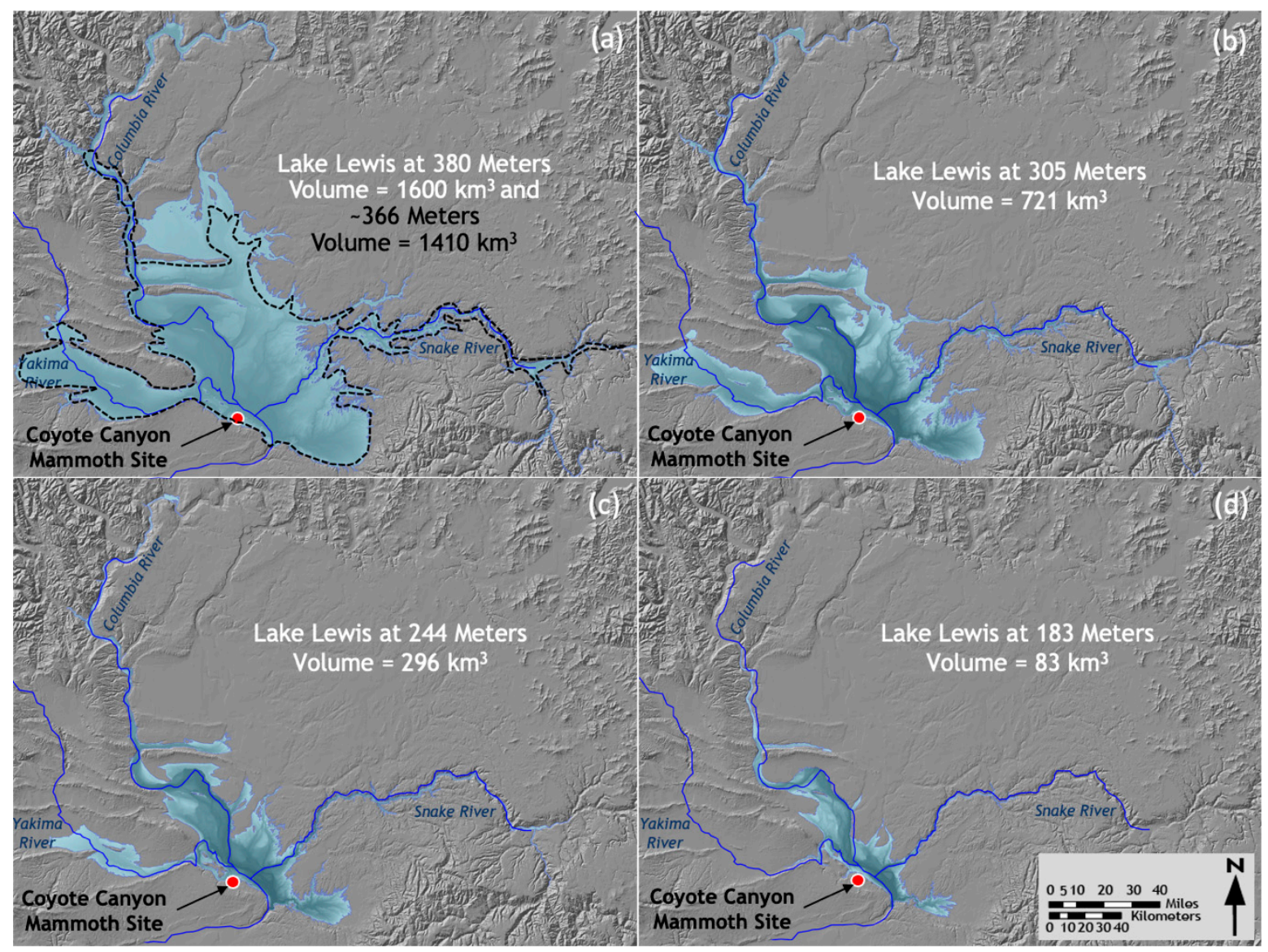

Figure 2. Schematic of the extent of hydraulically ponded flood waters of transient Lake Lewis assuming static flood stages at $380 \mathrm{~m}$ asl (a), $305 \mathrm{~m}$ asl (b), $244 \mathrm{~m}$ asl (c), and $183 \mathrm{~m}$ asl (d) [17]. Note that a flood stage of about $366 \mathrm{~m}$ asl, outlined in (a), would yield a volume of $1410 \mathrm{~km}^{3}$ [11].

Numerous mammoth sites have been found within slackwater flood deposits in the area impounded by Lake Lewis $[1,4,5,20,21]$. A radiocarbon age, calibrated to about $17.7 \pm 0.3 \mathrm{ka}$ cal BP, was reported for a mammoth tusk (from the Moxee City Mammoth Site) found in a sequence of three rhythmites in a high distal portion of Lake Lewis that extended up the Yakima Valley [14,22] (Figure 3, Table 1). While this tusk appears to have eroded from a prior location and redeposited by later Missoula floods, the slackwater sediments in which it was found were likely deposited soon after the mammoth's death [14]. The pooled mean value for two radiocarbon samples from CCMS was reported as $17.4 \pm 0.2 \mathrm{ka}$ cal BP [22] (Figure 3, Table 1). Here, a nearly complete, partially articulated skeleton was found within a sequence of at least seven rhythmites at an elevation of about $315 \mathrm{~m}$. Both the Moxee City Mammoth Site and CCMS have acceptable quantitative age estimates that constrain the Missoula floods. 


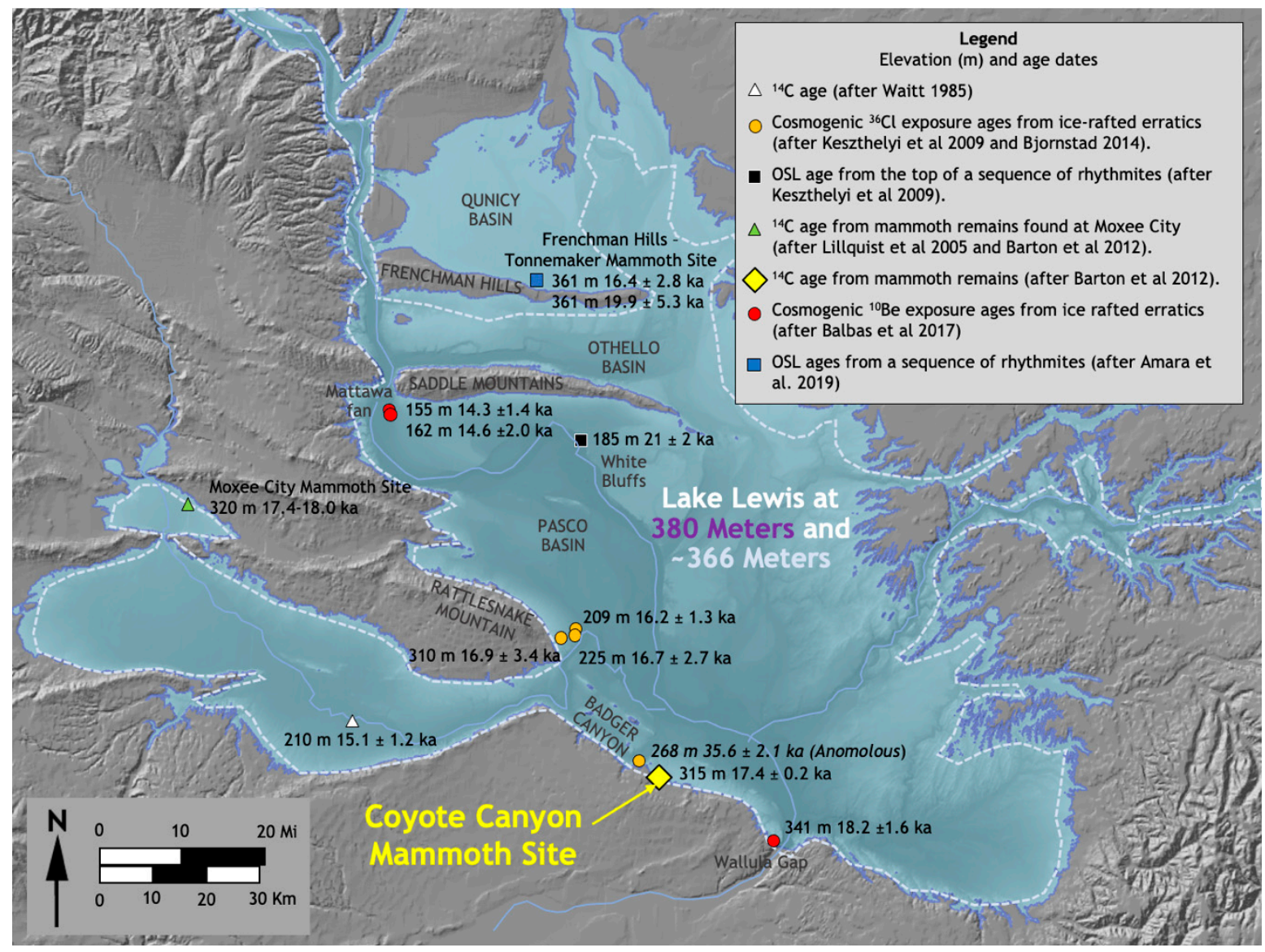

Figure 3. Extent of hydraulically ponded flood waters of Lake Lewis, assuming a flood stage of $380 \mathrm{~m}$ asl and a schematic outline at a flood stage of $366 \mathrm{~m}$ asl (dashed) [16,17], showing the locations of available numerical ages.

Table 1. Existing chronological data for Lake Lewis.

\begin{tabular}{|c|c|c|c|c|c|c|}
\hline Sample ID & Northing (Lat.) & $\begin{array}{l}\text { Easting } \\
\text { (Long.) }\end{array}$ & $\begin{array}{c}\text { Elevation } \\
\text { (m, asl) }\end{array}$ & $\begin{array}{c}\text { Analytical } \\
\text { Method }\end{array}$ & $\begin{array}{l}\text { Age } \\
\text { (ka) }\end{array}$ & Reference \\
\hline USGS-684 & 46.22628 & -119.99996 & 210 & ${ }^{14} \mathrm{C}$ & $15.1 \pm 1.2^{\mathrm{a}}$ & [13] \\
\hline MF-6 & 46.37878 & -119.50037 & 310 & ${ }^{36} \mathrm{Cl}$ & $16.9 \pm 3.4$ & {$[15,16]$} \\
\hline MF-7 & 46.38400 & -119.46353 & 209 & ${ }^{36} \mathrm{Cl}$ & $16.2 \pm 1.3$ & {$[15,16]$} \\
\hline MF-8 & 46.38093 & -119.46473 & 225 & ${ }^{36} \mathrm{Cl}$ & $16.7 \pm 2.7$ & {$[15,16]$} \\
\hline WB-k & 46.70369 & -119.45160 & 185 & OSL & $21 \pm 2$ & [15] \\
\hline CAMS 79942 & 46.56308 & -120.39552 & 320 & ${ }^{14} \mathrm{C}$ & $17.7 \pm 0.3$ & {$[14,22]$} \\
\hline Wk-32731\&2 & 46.15862 & -119.26480 & 315 & ${ }^{14} \mathrm{C}$ & $17.4 \pm 0.2$ & [22] \\
\hline MAT-3 & 46.71450 & -119.94356 & 155 & ${ }^{10} \mathrm{Be}$ & $14.3 \pm 1.3$ & [10] \\
\hline MAT-9 & 46.71987 & -119.94468 & 162 & ${ }^{10} \mathrm{Be}$ & $14.6 \pm 1.5$ & [10] \\
\hline WG-Baker & 46.04585 & -118.96192 & 341 & ${ }^{10} \mathrm{Be}$ & $18.2 \pm 1.6$ & [10] \\
\hline FHT-OSL-1 & 46.95954 & -119.56320 & 361 & OSL & $19.9 \pm 5.3$ & [23] \\
\hline FHT-OSL-3 & 46.95954 & -119.56320 & 361 & OSL & $16.4 \pm 2.8$ & [23] \\
\hline
\end{tabular}

a The radiocarbon age of 14,060 +/ - 450 yr B.P. initially reported [13], was calibrated using OxCal 4.4 (130) on 27 January / 2021 to yield a calibrated age of $16,304-13,921$ yrs, $95.4 \%$ probability.

Thirty-two cosmogenic ${ }^{10} \mathrm{Be}$ exposure ages from granitic boulders deposited by ice rafting or on flood deposits within distinct flood pathways have improved our understanding of the flood chronology [10]. Three of these samples are directly associated with the main body of former Lake Lewis (Figure 3). Two of these samples were from floodtransported boulders on the Mattawa fan at elevations of 155 and $162 \mathrm{~m}$ asl and yielded ages of $14.3 \pm 1.4$ and $14.6 \pm 2 \mathrm{ka}$ (Table 1). These boulders are believed to have been last transported by the last smaller flood(s) that came down the Columbia River, most likely 
from glacial Lake Columbia upon breakup of the Okanogan lobe of the Cordilleran Ice Sheet [10]. A third sample came from an ice-rafted erratic boulder found at a high elevation (341 m) at Wallula Gap (the only outlet for Lake Lewis) and yielded an age of $18.2 \pm 1.6 \mathrm{ka}$ (Table 1). This ice-rafted boulder is believed to be associated with one of the earliest and largest late Pleistocene Missoula flood(s) [10].

OSL ages of $19.9 \pm 5.3$ and $16.4 \pm 2.8$ ka have been reported from a sequence of Missoula flood deposits exposed in excavations of the Frenchman Hills-Tonnemaker (FHT) Mammoth Site $[23,24]$ (Table 1). The presence of MSH-S tephra, dated to about $16 \mathrm{ka}$ was also noted [25]. This is consistent with the uppermost (youngest) OSL age and provides a minimum age for the Missoula flood deposits at this site and a maximum age for deposition of the mammoth skeleton. This site, at an elevation of about $361 \mathrm{~m}$ asl, is located within the Quincy Basin, on the north edge of the Frenchman Hills, where flood stages reached over $400 \mathrm{~m}$ asl while cascading toward the Pasco Basin [11,19] (Figure 3).

OSL ages from CCMS and a nearby site were obtained to define the chronology of Missoula floods and other events recorded in the sediment record of the mammoth site [6]. These data provide important constraints for interpreting the geologic context of the mammoth site. The five chronological data points for Missoula flood deposits add to twelve existing ages for flood deposits within the main body (Pasco Basin) of Lake Lewis (Table 1).

\section{Study Sites}

\subsection{Coyote Canyon Mammoth Site}

The Coyote Canyon Mammoth Site (CCMS) is in Benton County, Washington $\left(46.1587^{\circ} \mathrm{N},-119.2648^{\circ} \mathrm{E}\right)$ at an elevation of $315 \mathrm{~m}$ asl ( $211 \mathrm{~m}$ above the Columbia River) on the southern shoreline of former Lake Lewis (Figures 1 and 3). Mammoth bones were initially discovered here in the fall of 1999 while quarrying fine-grained sediments for use as topsoil. The site was rediscovered in the Spring of 2008 when the land was listed for sale.

Formal excavation of the mammoth site, along the quarry face, has been ongoing since 2010. There are currently fourteen $2 \mathrm{~m} \times 2 \mathrm{~m}$ excavation units extending to different levels in an irregular stair-step fashion (Figure 4). Thus far, more than 152 mammoth bone specimens have been recovered from the site. These include left and right humeri, left radius, left scapula, thoracic, cervical and caudal vertebrae, ribs, metapodials, partial molars, and tusk fragments. The mammoth bones have been found in anatomical groupings within a relatively small area, approximately $10 \mathrm{~m} \times 6 \mathrm{~m}$, with some bones (e.g., the left humerus and left scapula) in near articulated position (Figure 5). There are no duplicate skeletal elements, suggesting that all bone specimens are from a single individual.

Stratigraphic interpretation of the site (Figure 6) suggests that there are at least seven slackwater flood beds [26-30]. However, differentiating individual flood beds is challenging in higher elevation back-flooded canyon areas, where graded bedding is less distinct and soft sediment deformation obscures lateral continuity of sedimentary structures and bedding planes. In some cases, multiple/repeat slackwater beds may well have been deposited as slope wash modified the soft sediment during waning stages. Primary sedimentary structures and bedding planes are particularly difficult to delineate within the mammoth bone bed. Radiocarbon dating of the left humerus lying within the sequence of Missoula flood deposits yielded an accelerator mass spectrometry (AMS) pooled age of death of about 17.4 $\pm 0.2(1 \sigma) \mathrm{ka}$ cal BP [22]. Numerous ice-rafted erratic (non-basalt) pebbles to boulder size rocks have been found within the mammoth bone bed immediately adjacent to or intermixed with the mammoth bones. Tentative provenance associations from a multi-lithologic cluster of ice-rafted erratic pebbles, co-located within a single iceberg feature, are consistent with the bedrock at the site of a Purcell Trench Lobe ice dam (Figure 1) and corresponding Missoula flood [31,32]. 


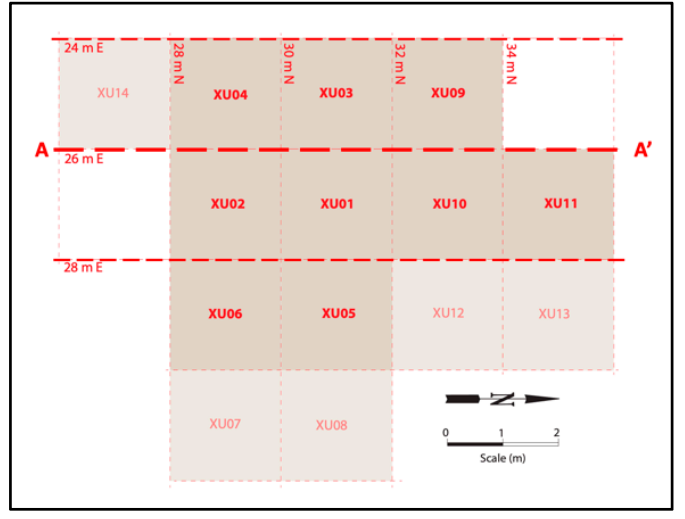

(a)

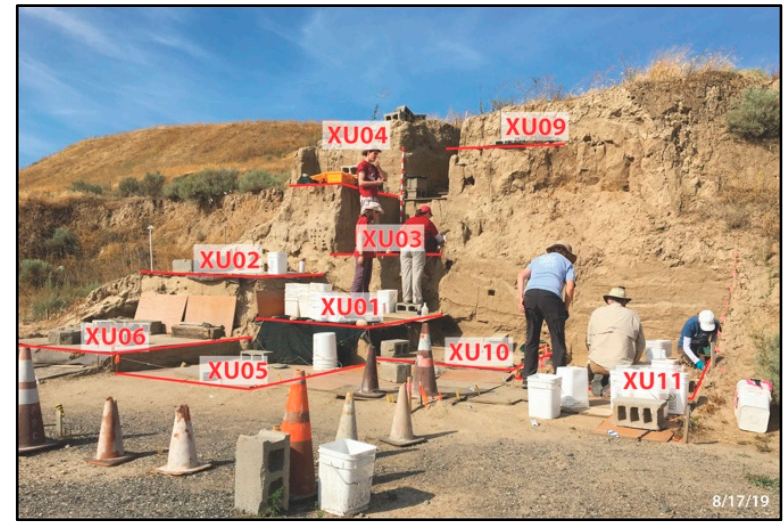

(b)

Figure 4. Layout of excavation units: (a) Shows the map of the three transects, including A-A', on to which the stratigraphy in Figure 6 is projected; (b) Shows the stair step configuration of the excavation units. Only the darker shaded units in (a) are labelled in (b).

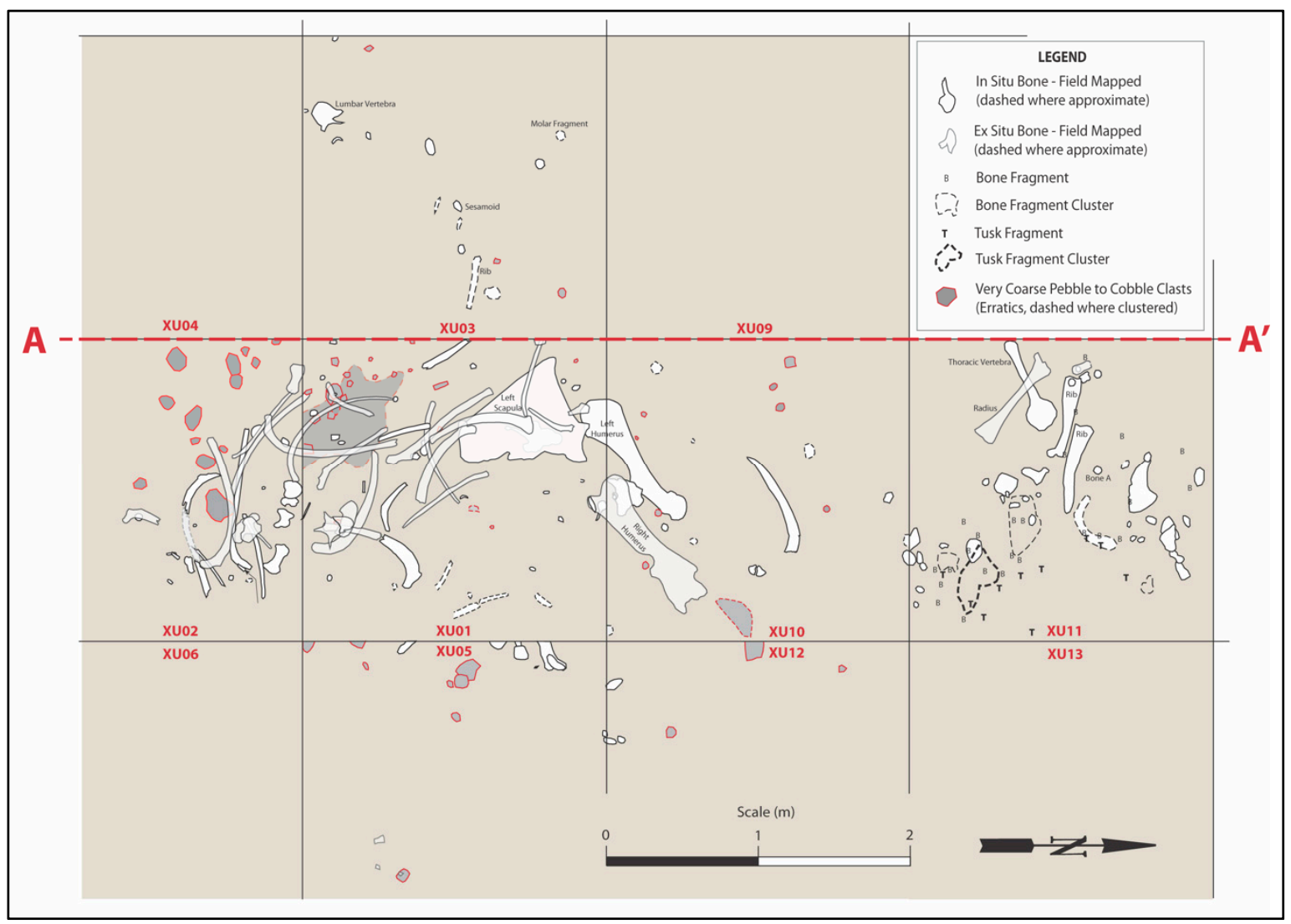

Figure 5. Distribution of bone specimens and ice-rafted erratics at the Coyote Canyon Mammoth Site through 2019, in plan view projected to multiple excavation unit floor levels (see Figure $4 \mathrm{~b}$ ). The line A-A' delineates the location of the stratigraphic cross section in Figure 6.

Stratigraphic interpretation suggests that several large Missoula floods inundated the Coyote Canyon area prior to deposition of the mammoth. Then, about $17.4 \mathrm{ka}$, another Missoula flood likely drowned and deposited the Coyote Canyon mammoth in this distal arm of former Lake Lewis adjacent to other flood debris such as ice-rafted erratics. The mammoth lay partially exposed at the surface, where it underwent scavenging, decay, and weathering [30]. Subsequent Missoula floods successively buried the mammoth remains. Cataclysmic flooding appears to have been followed by a period of subaerial exposure, loess 
deposition, reworking (by wind and bioturbation), and pedogenesis [30]. Eolian activity blanketed the site with about a meter of wind-blown loess. Rainwater and snowmelt cut into the loess deposits and left behind localized deposits of colluvial slope wash. However, the timing of this sequence of geologic events has been poorly constrained.

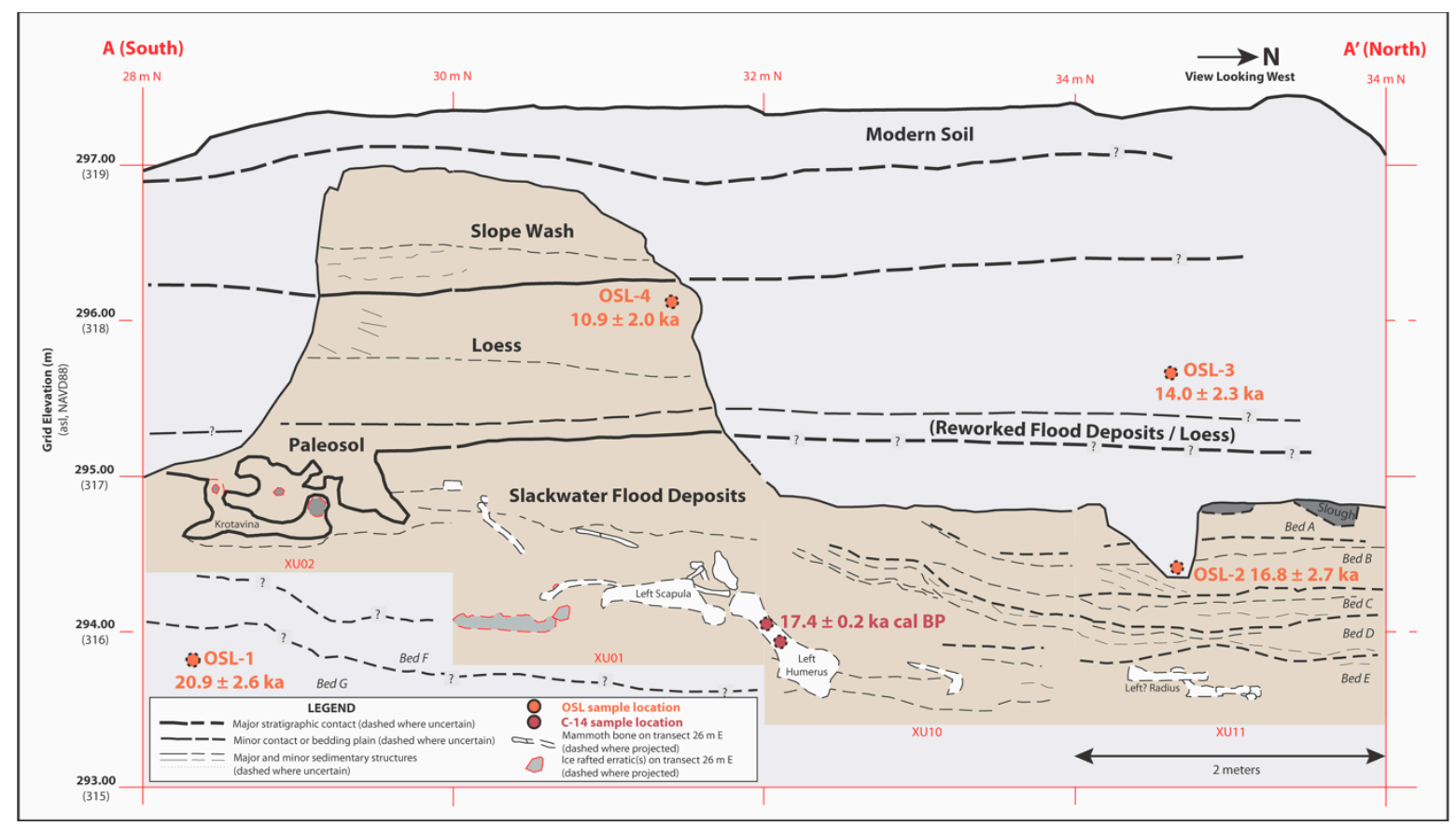

Figure 6. Stratigraphic interpretation of the CCMS excavation along a cross section (tan shading) looking west. See Figures $4 \mathrm{a}$ and 5 for location. The major stratigraphic units (projected to background and foreground excavation walls, shaded in gray) include (from oldest to youngest): a sequence of slackwater flood deposits, a paleosol, loess, and colluvial slope wash. Note the location of OSL and radiocarbon samples.

\subsection{Coyote Canyon South Hill-Mauldin Site}

OSL samples were also collected from the face of a nearby excavation cut located at $46.1592^{\circ} \mathrm{N},-119.2687^{\circ} \mathrm{E}$, approximately $300 \mathrm{~m}$ to the west-northwest of CCMS at an elevation of 315-320 m asl. Here, an isolated camel bone (Camelops hesternus metatarsal) was found within slackwater flood deposits [33]. A mean age for the metatarsal was reported as $25.2 \pm 0.2 \mathrm{ka}$ cal BP [34]. This site was designated the Coyote Canyon South Hill-Mauldin Site (CCSH-MS) and yielded a lower limiting (terminus post quem) OSL age of $16.5 \pm 2.4 \mathrm{ka}$ (CCCS-OSL-5) (note that this preliminary OSL age has since been revised to $17.4 \pm 2.6 \mathrm{ka}$, as shown in Figure 7) recovered from sediments sampled $\sim 50 \mathrm{~cm}$ below the metatarsal [33]. Based on the weathered bone taphonomy and the discrepancy of its radiocarbon age with the underlying OSL age and stratigraphic context, the bone is interpreted as a rip-up clast, eroded from nearby older strata, and redeposited within later flood deposits [33]. Logging of the stratigraphy suggests that as many as 13 slackwater flood beds may lie here (Figure 7). 


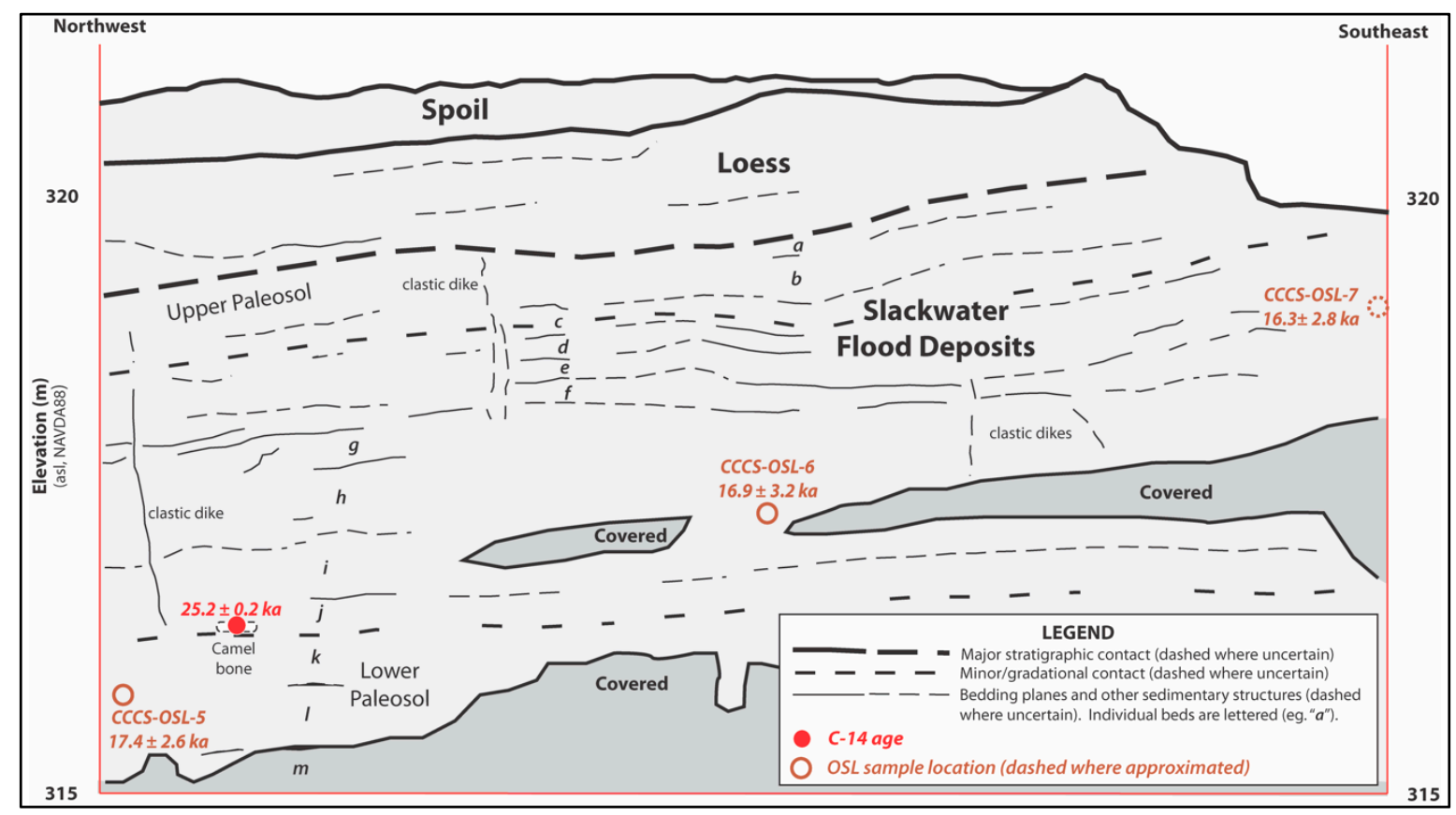

Figure 7. Stratigraphic interpretation of a measured section at CCSH-MS, where a Camelops hesternus metatarsal was found, approximately $300 \mathrm{~m}$ west-northwest of the CCMS excavation. Thirteen slackwater flood beds (designated by lower case letters) have been identified here. Note the location of OSL samples.

\section{Materials and Methods}

We collected seven samples for OSL analysis; four from the CCMS excavation (Figure 6) and three from the CCSH-MS cut face (Figure 7). Detailed sample information is provided in Table 2.

Table 2. Optically stimulated luminescence samples.

\begin{tabular}{cccccc}
\hline Sample ID & $\begin{array}{c}\text { USU } \\
\text { Number }\end{array}$ & $\begin{array}{c}\text { Northing } \\
(\text { Lat.) }\end{array}$ & $\begin{array}{c}\text { Easting } \\
\text { (Long.) }\end{array}$ & $\begin{array}{c}\text { Depth } \\
\mathbf{( m )}\end{array}$ & $\begin{array}{c}\text { Elevation } \\
\text { (m, asl NAVD 88) }\end{array}$ \\
\hline \multicolumn{7}{c}{ Coyote Canyon Mammoth Site (CCMS) } \\
\hline CCMS-OSL-1 & USU-2156 & 46.15864 & -119.26479 & 4 & 315.7 \\
CCMS-OSL-2 & USU-2157 & 46.15870 & -119.26482 & 3.65 & 316.3 \\
CCMS-OSL-3 & USU-2158 & 46.15870 & -119.26482 & 2.2 & 317.5 \\
CCMS-OSL-4 & USU-2159 & 46.15867 & -119.26484 & 1.8 & 318.0 \\
\hline \multicolumn{7}{c}{ Coyote Canyon Camel Site (CCCS), also known as Coyote Canyon South Hill-Mauldin Site (CCSH-MS) } \\
\hline \multicolumn{7}{c}{ CCCS-OSL-5 } & USU-2160 & 46.15923 & -119.26855 & 5.5 & 316.3 \\
CCCS-OSL-6 & USU-2161 & 46.15923 & -119.26850 & 4.1 & 317.7 \\
CCCS-OSL-7 & USU-2162 & 46.15922 & -119.26845 & 2.6 & 319.2 \\
\hline
\end{tabular}

\subsection{Sample Collection}

Samples for OSL analysis were collected 21 October 2015, using $3.8 \mathrm{~cm}$ diameter $\mathrm{x}$ $20 \mathrm{~cm}$ lengths of stainless-steel electrical conduit fitted with a $\sim 5 \mathrm{~cm}$ diameter galvanized cleanout plug on the driving end. The open end of the sampling tube was fitted with a Styrofoam plug to keep the sediment packed while driving the sampler into the target sediment. The sampling tubes were driven into the target sediment using a $1.1 \mathrm{~kg}$ sledgehammer (Figure 8). Once removed from the outcrop, the packed sample tube was immediately capped with a vinyl end cap and secured with tape (Figure 8). 


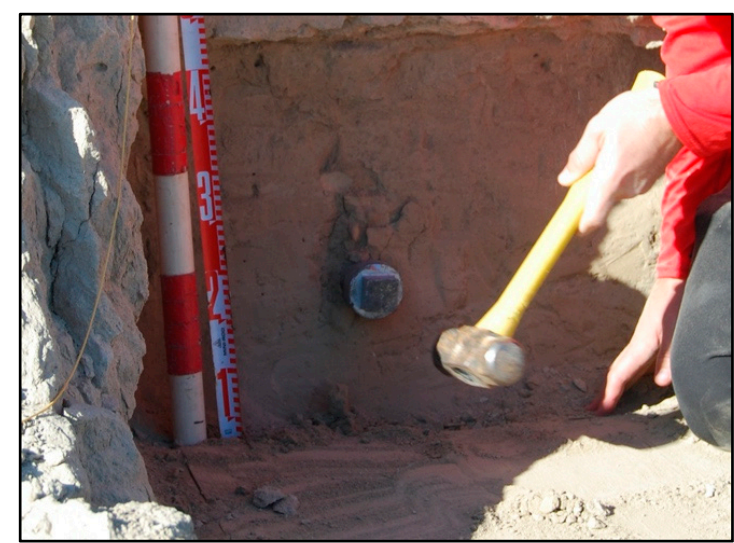

(a)

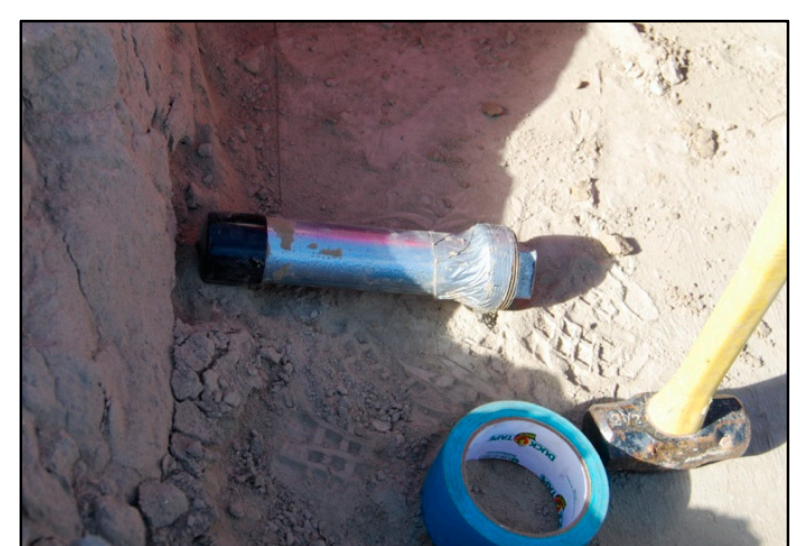

(b)

Figure 8. OSL sampling of CCMS-OSL-01: (a) Illustrates the sample tube being driven into the target sediments; (b) Shows the sample tube after retrieval and capping.

Samples were collected for dose-rate calculations and water content from a $30-\mathrm{cm}$ diameter semi-spherical region surrounding each sampling tube. These samples included the materials removed during exhumation of the sample tube.

\subsection{Optically Stimulated Luminescence Analyses}

Optically stimulated luminescence (OSL) [35] is a dating technique used to determine how long a sedimentary deposit has been buried (i.e., the last time quartz was exposed to sunlight). As sediment is transported it is exposed to sunlight. Once this sediment is deposited and subsequently buried, it is removed from light and is exposed to low levels of natural radiation in the surrounding sediment. Over time, quartz minerals accumulate a luminescence signal as ionizing radiation excites electrons within parent nuclei in the crystal lattice. A certain percent of the freed electrons become trapped in defects or holes in the crystal lattice of the quartz sand grains (referred to as luminescent centers) and accumulate over time [36]. The amount of natural radiation from the surrounding sediment to which the sediment grains were exposed during burial is termed the "equivalent dose" $\left(D_{E}\right)$, measured in Grays (Gy). By dividing the $\mathrm{D}_{\mathrm{E}}$ by the environmental dose rate, measured in $\mathrm{Gy} / \mathrm{kyr}$, one can obtain an age estimate for the time of deposition and burial.

The environmental radioactive dose rate was calculated based on water content, sediment chemistry, and cosmic contribution $[36,37]$. Sediment concentrations of $U$, Th, $\mathrm{K}$ and $\mathrm{Rb}$ were determined using inductively coupled plasma mass spectrometry (ICPMS) and inductively coupled plasma atomic emission spectroscopy (ICP-AES) techniques. Standard conversion factors [38] were used to calculate their contributions to the dose-rates. The contribution of cosmic radiation to the dose rate was calculated using sample depth, elevation, and latitude/longitude [39].

Exposure to sunlight during transportation generally removes the accumulated dose from previous burials - effectively zeroing any previous luminescence signal. However, in some environments the sand grains may not be exposed to sufficient light to fully remove the luminescence signal. These potentially incompletely zeroed sediments are often referred to as "partially bleached". Some researchers believe this phenomenon may occur in megaflood (e.g., Missoula flood) related sediments [15].

OSL analyses were conducted at the Utah State University (USU) Luminescence Laboratory. All samples were opened and processed under dim amber safelight conditions within the lab. Sample processing for quartz OSL dating followed standard procedures involving sieving, $\mathrm{HCl}$ and bleach treatments, heavy mineral separation at $2.72 \mathrm{~g} / \mathrm{cm}^{3}$, and acid treatments with $\mathrm{HCl}$ and $\mathrm{HF}$ to isolate the quartz component of a narrow grain-size range of $63-125 \mu \mathrm{m}$. The purity of the quartz samples was checked by measurement with infra-red stimulation to detect the presence of feldspar. 
OSL samples were analyzed following the single-aliquot regenerative-dose (SAR) technique [40] on small aliquots ( $1 \mathrm{~mm}$ diameter, 40 grains per disk) of fine quartz sand. Optical measurements were performed on Risø TL/OSL Model DA-20 readers, with stimulation by blue-green light emitting diodes (LED) $(470 \pm 30 \mathrm{~nm})$ and the luminescence signal was detected through 7.5-mm ultraviolet filters (U-340) over $40 \mathrm{~s}$ (250 channels) at $125{ }^{\circ} \mathrm{C}$ with LED diodes at $90 \%$ power $\left(36-45 \mathrm{~mW} / \mathrm{cm}^{2}\right)$. Luminescence signals were calculated by subtracting the average of the last $5 \mathrm{~s}$ (background signal) from the sum of first $0.7 \mathrm{~s}$ (4 channels) of signal. Ages were calculated using the Minimum Age Model (MAM) [41] to compensate for the effects of "partially bleaching" [15].

\section{Results}

Table 3 provides the analytical results for moisture content and radioelement chemistry of the samples collected during exhumation of the OSL samples, as well as the calculated cosmic radiation dose contribution. Table 4 provides the results from the OSL analyses. The OSL ages are reported at $2 \sigma$ standard error.

Table 3. Moisture content and radioelement concentrations for samples collected during exhumation of OSL samples.

\begin{tabular}{|c|c|c|c|c|c|c|}
\hline Sample Num. & $\underset{(\%)}{\text { In-Situ } \mathrm{H}_{2} \mathrm{O}}$ & $\underset{(\%)^{2}}{K}$ & $\mathrm{Rb}(\mathrm{ppm})^{2}$ & Th $(\mathrm{ppm})^{2}$ & $\mathrm{U}(\mathrm{ppm})^{2}$ & $\begin{array}{l}\text { Cosmic } \\
\text { (Gy/kyr) }\end{array}$ \\
\hline \multicolumn{7}{|c|}{ Coyote Canyon Mammoth Site (CCMS) } \\
\hline CCMS-OSL-1 & 9.8 & $2.02 \pm 0.05$ & $93.2 \pm 3.7$ & $11.2 \pm 1.0$ & $2.3 \pm 0.2$ & $0.13 \pm 0.01$ \\
\hline CCMS-OSL-2 & 6.9 & $1.74 \pm 0.04$ & $77.9 \pm 3.1$ & $11.1 \pm 1.0$ & $2.6 \pm 0.2$ & $0.14 \pm 0.01$ \\
\hline CCMS-OSL-3 & $1.5(9.8)$ & $1.67 \pm 0.04$ & $76.4 \pm 3.1$ & $9.5 \pm 0.9$ & $1.9 \pm 0.13$ & $0.17 \pm 0.02$ \\
\hline CCMS-OSL-4 & $2.2(9.8)$ & $1.65 \pm 0.04$ & $74.8 \pm 3.0$ & $9.0 \pm 0.8$ & $1.8 \pm 0.1$ & $0.18 \pm 0.02$ \\
\hline \multicolumn{7}{|c|}{ Coyote Canyon Camel Site (CCCS), a.k.a. Coyote Canyon South Hill-Mauldin Site (CCSH-MS) } \\
\hline CCCS-OSL-5 & $1.9(9.8)$ & $1.88 \pm 0.05$ & $81.0 \pm 3.2$ & $12.4 \pm 1.1$ & $2.1 \pm 0.2$ & $0.11 \pm 0.01$ \\
\hline CCCS-OSL-6 & $1(9.8)$ & $2.15 \pm 0.05$ & $93.4 \pm 3.7$ & $14.3 \pm 1.3$ & $2.4 \pm 0.2$ & $0.13 \pm 0.01$ \\
\hline CCCS-OSL-7 & $1.1(9.8)$ & $1.96 \pm 0.05$ & $82.9 \pm 3.3$ & $9.6 \pm 0.9$ & $2.0 \pm 0.1$ & $0.16 \pm 0.021$ \\
\hline
\end{tabular}

${ }^{1}$ In situ value reported, value in parentheses used as moisture content in dose rate calculation. ${ }^{2}$ Radioelemental concentrations determined by ALS Chemex using ICP-MS and ICP-AES techniques.

Table 4. Optically stimulated luminescence results.

\begin{tabular}{|c|c|c|c|c|c|c|}
\hline $\begin{array}{c}\text { Sample ID } \\
\text { (USU Number) }\end{array}$ & Depth (m) & $\begin{array}{c}\text { Num. of } \\
\text { Aliquots }{ }^{1}\end{array}$ & $\begin{array}{c}\text { Dose Rate } \\
\text { (Gy/kyr) }\end{array}$ & $\mathrm{D}_{\mathrm{E}}^{2} \pm 2 \sigma(\mathrm{Gy})$ & $\begin{array}{c}\mathrm{OD}^{3} \\
(\%)\end{array}$ & $\begin{array}{c}\text { OSL Age } \pm 2 \sigma \\
\text { (ka) }\end{array}$ \\
\hline \multicolumn{7}{|c|}{ Coyote Canyon Mammoth Site (CCMS) } \\
\hline $\begin{array}{l}\text { CCMS-OSL-1 } \\
\text { (USU-2156) }\end{array}$ & 4 & $20(26)$ & $3.22 \pm 0.17$ & $67.15 \pm 4.70$ & $7.4 \pm 4.5$ & $20.87 \pm 2.55$ \\
\hline $\begin{array}{l}\text { CCMS-OSL-2 } \\
\text { (USU-2157) }\end{array}$ & 3.65 & $16(25)$ & $3.11 \pm 0.13$ & $52.13 \pm 7.27$ & $25.5 \pm 5.4$ & $16.77 \pm 2.70$ \\
\hline $\begin{array}{l}\text { CCMS-OSL-3 } \\
\text { (USU-2158) }\end{array}$ & 2.2 & $19(24)$ & $2.73 \pm 0.14$ & $38.19 \pm 4.86$ & $22.5 \pm 5.4$ & $14.01 \pm 2.26$ \\
\hline $\begin{array}{l}\text { CCMS-OSL-4 } \\
\text { (USU-2159) }\end{array}$ & 1.8 & $15(18)$ & $2.65 \pm 0.14$ & $28.89 \pm 4.58$ & $26.8 \pm 6.4$ & $10.88 \pm 2.04$ \\
\hline \multicolumn{7}{|c|}{ Coyote Canyon Camel Site (CCCS), a.k.a. Coyote Canyon South Hill—Mauldin Site (CCSH-MS) } \\
\hline $\begin{array}{c}\text { CCCS-OSL-5 } \\
\text { (USU-2160) }\end{array}$ & 5.5 & $11(42)$ & $3.10 \pm 0.12$ & $53.86 \pm 6.74$ & $9.0 \pm 8.6$ & $17.39 \pm 2.59$ \\
\hline $\begin{array}{l}\text { CCCS-OSL-6 } \\
\text { (USU-2161) }\end{array}$ & 4.1 & $10(48)$ & $3.55 \pm 0.14$ & $59.84 \pm 10.39$ & $22.5 \pm 7.2$ & $16.85 \pm 3.23$ \\
\hline $\begin{array}{l}\text { CCCS-OSL-7 } \\
\text { (USU-2162) }\end{array}$ & 2.6 & $23(38)$ & $3.01 \pm 0.12$ & $49.04 \pm 7.374$ & $21.9 \pm 4.1$ & $16.28 \pm 2.77$ \\
\hline
\end{tabular}

${ }^{1}$ Age analysis using the single-aliquot regenerative-dose (SAR) procedure [40] on 1-mm small-aliquots of 63-125 $\mu \mathrm{m}$ quartz sand. Number of aliquots used in age calculation and number of aliquots analyzed in parentheses. ${ }^{2}$ Equivalent dose $\left(D_{\mathrm{E}}\right)$ calculated using the Minimum Age Model (MAM) [41]. ${ }^{3}$ Overdispersion (OD) represents variance in $\mathrm{D}_{\mathrm{E}}$ data beyond measurement uncertainties, $\mathrm{OD}>20 \%$ may indicate significant scatter due to depositional or post-depositional processes. 
Figure 6 places the Coyote Canyon Mammoth Site (CCMS) OSL age results in the context of the stratigraphy and previously reported radiocarbon age for the left humerus [22]. These data indicate that the slackwater flood deposits exposed here range in age from $20.9 \pm 2.6 \mathrm{ka}$ to $16.8 \pm 2.7 \mathrm{ka}$. This is consistent with the radiocarbon age of $17.4 \pm 0.2 \mathrm{ka}$ cal BP for the left humerus [22]. Overlying loess deposits range in age from $14.0 \pm 2.3 \mathrm{ka}$ to $10.9 \pm 2.0 \mathrm{ka}$, suggesting a maximum hiatus of about 2.8 thousand years following deposition of the Missoula flood deposits-giving rise to reworking of the paleosurface and paleosol development.

Figure 7 places the CCSH-MS OSL results in the context of the interpreted stratigraphy and radiocarbon age for the Camelops hesternus metatarsal. These data indicate that slackwater flood deposits exposed here range from $17.4 \pm 2.6 \mathrm{ka}$ to $16.3 \pm 2.8 \mathrm{ka}$, comparable to the upper flood deposits exposed at CCMS. The younger age of these flood deposits compared to the $25.2 \pm 0.2 \mathrm{ka}$ cal BP age of the Camelops hesternus metatarsal supports interpretation that the metatarsal was eroded from older strata and redeposited by Missoula floods some 8000 years after its death [33].

\section{Discussion}

The seven new OSL ages on slackwater flood deposits and overlying loess not only provide key constraints on the timing of geologic events at CCMS, but also expand our understanding of the dynamic nature and chronology of former Lake Lewis flood stages.

\subsection{Chronology of Geologic Events at the Coyote Canyon Mammoth Site}

At least seven Missoula-flood beds are exposed at the Coyote Canyon Mammoth Site (CCMS) at an elevation of 315-319 $\mathrm{m}$ asl. The oldest flood deposits yielded an OSL age of at least $20.9 \pm 2.6 \mathrm{ka}$, while the youngest yielded an OSL age of at least $16.8 \pm 2.7 \mathrm{ka}$. These ages bracket the radiocarbon age of $17.4 \pm 0.2 \mathrm{ka}$ cal BP for the left humerus of the Coyote Canyon mammoth found within the middle of the flood deposit sequence. OSL ages from the CCSH-MS stratigraphic section located approximately $300 \mathrm{~m}$ to the west-northwest at a similar elevation (315-320 m asl) yielded similar ages (17.4 $\pm 2.6 \mathrm{ka}$ to $16.3 \pm 2.8 \mathrm{ka}$ ) for a sequence of as many as 13 slackwater flood beds. Note that differentiating individual flood beds in this high distal canyon area is challenging because graded bedding, other sedimentary structures and bedding planes are indiscrete and discontinuous. Slope wash and soft-sediment deformation during waning flood stages may also have produced multiple beds from a single flood. However, collectively, these data suggest that at least 7 to 13 Missoula floods occurred between 20.9 and $16.3 \mathrm{ka}$ that created a sufficiently high hydraulically ponded flood stage to inundate the Coyote Canyon area. This is consistent with larger and less frequent outburst floods from a larger self-dumping Lake Missoula prior to late-glacial thinning of the ice dam $[1,2,11,13]$.

The relationship of flood rhythmites and ice-rafted erratics with the concentration of partially articulated mammoth bones suggests that one of these floods that occurred about 17.4 ka most likely led to the demise of the Coyote Canyon mammoth and deposition of its carcass on an ancient shoreline of Lake Lewis. Here, the carcass underwent scavenging, decay, and weathering before its burial by successive Missoula floods [30] and loess.

OSL dating of loess deposits overlying a paleosol at the top of the flood deposits provide a minimum age for the paleosol of at least $14.0 \pm 2.3 \mathrm{ka}$. This suggests there was a hiatus in deposition after the last Missoula flood deposit that may have lasted as much as 2.3 thousand years during which the site was exposed to subaerial processes including reworking (by wind and bioturbation) and pedogenesis [30]. Loess deposition over the next $>3.1$ thousand years $(14.0 \pm 2.3$ to $10.9 \pm 2.0 \mathrm{ka})$ then blanketed the site with at least a meter of loess. Rainwater and snowmelt subsequently eroded the loess deposits and left behind localized deposits of colluvial slope wash. The youngest OSL age for the loess $(10.9 \pm 2.0 \mathrm{ka})$ provides a maximum age (terminus post quem) for the deposition of the slope wash. 


\subsection{Implications on Hydraulically Ponded Flood Stages for Former Lake Lewis}

The timing of geologic events at CCMS suggests at least seven to 13 Missoula floods between $20.9 \pm 2.6 \mathrm{ka}$ and $16.3 \pm 2.8 \mathrm{ka}$ produced hydraulically ponded flood stages exceeding 315-320 m asl, sufficient to inundate the Coyote Canyon area and deposit finegrained graded beds of sediment (rhythmites) and ice-rafted erratics. OSL and radiocarbon ages from CCMS and CCSH-MS are consistent with ages that suggest at least one flood stage exceeded $310 \mathrm{~m}$ asl $16.9 \pm 3.4 \mathrm{ka}$ [15] and that perhaps the largest flood stages exceeded $341 \mathrm{~m}$ asl $18.2 \pm 1.6 \mathrm{ka}$ [10], Figure 9. Note that ages of $16.2 \pm 1.3 \mathrm{ka}$ and $16.7 \pm 2.7 \mathrm{ka}$ were reported from erratics at elevations of 209 and $225 \mathrm{~m}$ asl along the northeast flank of Rattlesnake Mountain $[15,16]$. As with all ages from Missoula flood debris (erratics, sediments, mammoth bones, etc.), their elevations must be taken as the minimum elevation of the contributing flood stage, because the actual water level could have been higher. This is particularly true where the water column must have been sufficiently thick for enough suspended sediment to settle out to accumulate rhythmites decimeters thick.

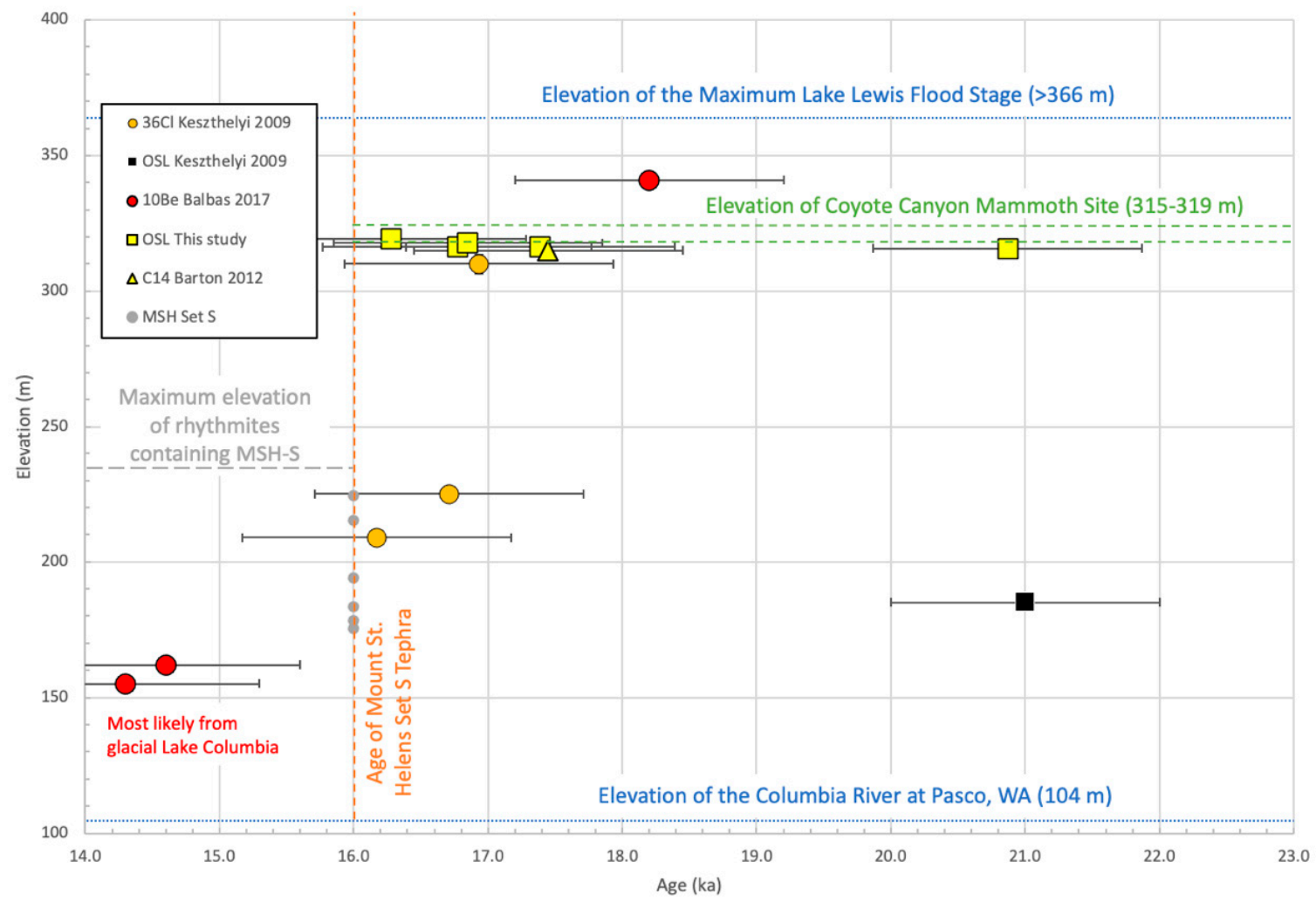

Figure 9. Graph of OSL and radiocarbon ages from the Coyote Canyon area (in yellow) compared with other available ages for Missoula flood deposits (rhythmites and erratics) from the main body of Lake Lewis (within the Pasco Basin), relative to their elevations.

Notably absent from elevations exceeding $315 \mathrm{~m}$ asl in the Coyote Canyon area are slackwater flood deposits containing the MSH-S tephra (dated at about $16 \mathrm{ka}$ ). However, rhythmites containing the MSH-S tephra are exposed in quarries located $3.8 \mathrm{~km}$ north of CCMS at an elevation of about $176 \mathrm{~m}$ asl along Ridgeline Drive, Kennewick, Washington. Here, eight rhythmites have been identified overlying the tephra layers (Figure 10). Up to 31 rhythmites have been identified overlying the MSH-S tephra $[1,8]$ and at least 28 underlying it [1]. At least $\sim 75$ floods may have preceded MSH-S, followed by 30 or more afterwards, with 59 floods able to backflood the Walla Walla valley [11]. While exposures of rhythmites containing MSH-S tephra are quite common in southeastern Washington below an elevation of $275 \mathrm{~m}$ asl [1], in the slackwater areas of Lake Lewis (e.g., the southern Pasco Basin, Yakima Valley, and Walla Walla Valley), they have not been found above about $230 \mathrm{~m}$ (Table 5). A number of researchers have noted that floods younger than MSH-S 
( $16 \mathrm{ka})$ were generally smaller than earlier floods, and that this is consistent with smaller and more frequent outburst floods from a smaller self-dumping Lake Missoula created by thinner late-glacial ice dams $[1,2,11,13,18]$.

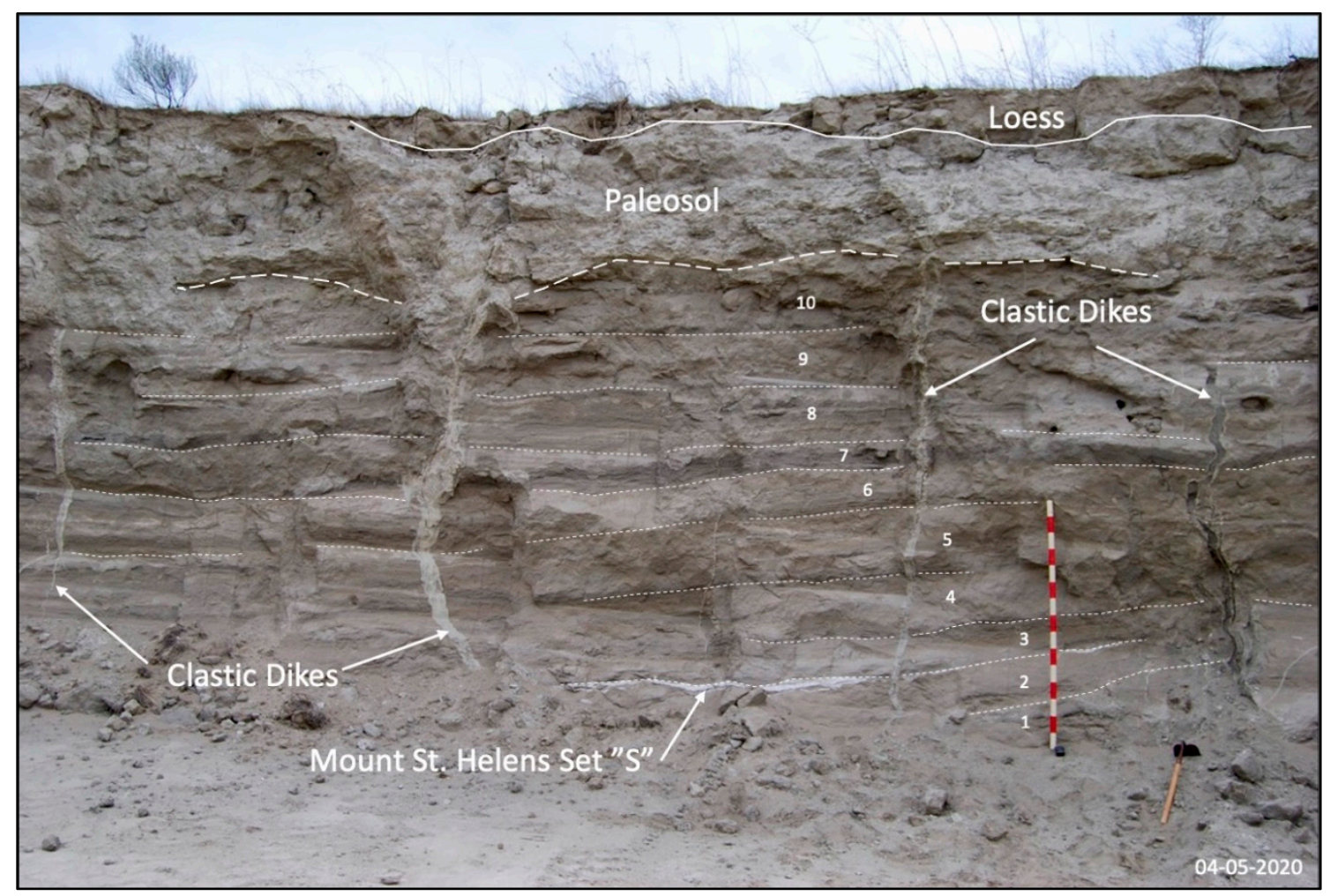

Figure 10. Exposure of at least 10 rhythmites at the Ridgeline South quarry, 8 of them overlying the MSH-S tephra. This site is $140 \mathrm{~m}$ lower than CCMS, which lacks the MSH-S tephra. Elevation at the base of the Jacob staff was measured using a handheld global positioning system (GPS) as $179 \mathrm{~m}$ asl.

Table 5. Approximate elevation at the top of selected rhythmite sections containing MSH-S. Elevations were estimated using Google Earth Pro unless otherwise noted.

\begin{tabular}{ccccc}
\hline Location ID & Reference & $\begin{array}{c}\text { Northing } \\
\text { (Lat.) }\end{array}$ & $\begin{array}{c}\text { Easting } \\
\text { (Long.) }\end{array}$ & $\begin{array}{c}\text { Elevation } \\
\text { (m, asl) }\end{array}$ \\
\hline & Within Main Body of Lake Lewis & & \\
\hline Ridgeline South & Personal Observation & $46.19316^{\text {a }}$ & $-119.26243^{\text {a }}$ & $184^{\text {a }}$ \\
Ridgeline North & Personal Observation & 46.19479 & -119.26172 & 177 \\
Badger Canyon & Bjornstad (2006) [19] & 46.24045 & -119.47294 & 194 \\
Benton City & Bjornstad (2006) [19] & 46.27217 & -119.50589 & 183 \\
Dry Creek & Personal Observation/Personal Comm. & 46.50073 b & $-119.72222^{b}$ & $224{ }^{b}$ \\
US Ecology & Bjornstad 8/30/05 & 46.53380 & -119.55769 & 215 \\
Red Mountain & Bergeron et al. (1987) [42], Smith (1993) [18] & 46.28154 & -119.40563 & 178 \\
\hline Bjornstad (2006) [19] & In Tributary Valleys/Basins & & \\
\hline Burlingame Canyon & Waitt (1980, 1985) [1,13] & 46.02302 & -118.59259 & 180 \\
Mabton & Waitt (1985) [13], MacEachern et al. (2013) [3] & 46.22628 & -119.99996 & 210 \\
Granger & Last et al. (2008) [43], Busacca et al. (2008) [44] & 46.31966 & -120.14680 & 224 \\
Zillah & Waitt (1980) [1], Norman et al. (2004) [45] & 46.39880 & -120.25907 & 227 \\
\hline
\end{tabular}

${ }^{a}$ GPS measurements made on $4 / 5 / 2020 .{ }^{b}$ GPS measurements made on 8/30/2005. 
Late Pleistocene outburst megafloods mostly from glacial Lake Missoula repeatedly created a transient lake, commonly known as Lake Lewis, due to downstream constrictions in the Columbia River. This study indicates that some early Missoula floods (before about $16.3 \mathrm{ka}$ ) created hydraulically ponded flood stages of former Lake Lewis that exceeded $315-320 \mathrm{~m}$ asl and suggests that later floods (after about $16.0 \mathrm{ka}$ ) produced flood stages less than that, generally not exceeding about $230 \mathrm{~m}$ asl. This study is consistent with current understanding that dozens of late Pleistocene megafloods occurred between $\sim 20 \mathrm{ka}$ and $14 \mathrm{ka}[2,7-10]$ and that earlier floods were larger than later ones $[1,2,7,10-15,18]$. We acknowledge that floods with larger discharges may not necessarily have created higher Lake Lewis flood stages due to the timing and magnitudes of flood waters passing through the various tortuous routes on the way to the Pasco Basin. However, it does appear that early ( $>16 \mathrm{ka}$ ) flood stages were higher than later $(<16 \mathrm{ka})$ flood stages. This is consistent with younger smaller outburst floods from a smaller self-dumping Lake Missoula created by thinner late-glacial ice dams $[1,2,11,13]$.

We recognize that there are uncertainties in the number of flood rhythmites exposed at CCMS and other locations within the Lake Lewis area, as well as uncertainties in their numerical ages (many with standard errors of \pm 2 to $3 \mathrm{ka}$ ). Continued excavation and borehole sampling at CCMS combined with additional age dating will undoubtedly improve our understanding of how Missoula Floods and other geologic events impacted this site.

The sedimentological features left by Lake Lewis, formed by hydraulic ponding of Missoula flood waters behind constrictions in the downstream drainage, provide good evidence on the dynamic behavior of these outburst megafloods. These included some of the largest glacial lake outburst floods on Earth [46]. The dating of slackwater rhythmites and ice-rafted erratics on the paleoshorelines of Lake Lewis provides good evidence for the elevation and timing of various flood stages and their impact on CCMS and other mammoth sites. Sedimentary deposits from other glacial lake outburst floods have also been found to be rich in mammoth bones [47]. However, most of these sites lack sedimentological evidence from hydraulically ponded slackwater areas. Instead, analysis of depositional processes and ages rely heavily on sedimentological features of outwash plains (sandurs) associated with the floods [48].

Author Contributions: Conceptualization, G.V.L. and T.M.R.; methodology, T.M.R.; validation, T.M.R.; formal analysis, G.V.L. and T.M.R.; investigation, G.V.L. and T.M.R.; resources, G.V.L. and T.M.R.; data curation, G.V.L. and T.M.R.; writing-original draft preparation, G.V.L.; writingreview and editing, G.V.L. and T.M.R.; visualization, G.V.L.; supervision, G.V.L. and T.M.R. project administration, G.V.L.; funding acquisition, G.V.L. and T.M.R. All authors have read and agreed to the published version of the manuscript.

Funding: This research received no external funding. Funding for OSL analyses and labor was provided by the Mid-Columbia Basin Old Natural Education Sciences (MCBONES) Research Center Foundation and Utah State University.

Data Availability Statement: Data is contained within the article. The data presented in this study are available on request from the corresponding author.

Acknowledgments: Numerous MCBONES volunteers helped with excavation and research at the site. We especially acknowledge Bax R. Barton, research director, and Gary C. Kleinknecht, education director, for their many contributions overseeing and operating this site. Special thanks go to Kirk Townsend (Utah State University) for his support in collection of the OSL samples, and Harriet Cornachione (Utah State University) who helped with sample processing. We also want to thank Mark Amara, Bruce Bjornstad and Stephen Reidel for their technical reviews, comments, and suggestions during this study. Finally, we thank the peer reviewers, whose comments greatly improved the quality of this manuscript.

Conflicts of Interest: The authors declare no conflict of interest. 


\section{References}

1. Waitt, R.B. About forty last-glacial Lake Missoula jökulhlaups through southern Washington. J. Geol. 1980, 88, 653-679. [CrossRef]

2. Atwater, B.F. Pleistocene glacial-lake deposits of the Sanpoil River Valley, northeastern Washington. Geol. Soc. Am. Bull. 1986, 1661. [CrossRef]

3. MacEachern, J.A.; Roberts, M.C. Ichnological evidence of jökulhlaup deposit recolonization from the Touchet Beds, Mabton, WA, USA. Quat. Res. 2013, 79, 37-48. [CrossRef]

4. Last, G.V.; Winsor, K. Impacts of Ice Age floods on Pleistocene mammoths of Southeastern Washington. In Abstracts with Programs, Cordilleran Section, Proceedings of the 103rd Annual Meeting, Bellingham, WA, USA, 4-6 May 2007; Geological Society of America: Boulder, CO, USA, 2007; Volume 39, p. 25. Available online: https://gsa.confex.com/gsa/2007CD/webprogram/Paper121251. html (accessed on 30 June 2021).

5. Barton, B.R. Some Notable Finds of Columbian Mammoths from Washington State; Washington Geological Survey: Olympia, WA, USA, 1999; Volume 27, pp. 23-27. Available online: https:/ / file.dnr.wa.gov/publications/ger_washington_geology_1999_v27_ no2-3-4.pdf\#page=23 (accessed on 30 June 2021).

6. Last, G.V.; Rittenour, T.M. Chronology of Missoula Flood deposits and the demise of the Coyote Canyon Mammoth, Benton County, Washington. In Abstracts with Programs, Rocky Mountain Section, Proceedings of the 72nd Annual Meeting, Provo, UT, USA, 5 May 2020; Volume 52, No. 3. [CrossRef]

7. Benito, G.; O'Connor, J.E. Number and size of last-glacial Missoula Floods in the Columbia River Valley between the Pasco Basin, Washington, and Portland, Oregon. Geol. Soc. Am. Bull. 2003, 115, 624-638. [CrossRef]

8. Clague, J.J.; Barendregt, R.; Enkin, R.J.; Foit, F.F. Paleomagnetic and tephra evidence for tens of Missoula floods in southern Washington. Geology 2003, 31, 247-253. [CrossRef]

9. Waitt, R.B. Megafloods and Clovis cache at Wenatchee, Washington. Quat. Res. 2016, 85, 430-444. [CrossRef]

10. Balbas, A.M.; Barth, A.M.; Clark, P.U.; Clark, J.; Caffee, M.; O'Connor, J.; Baker, V.R.; Konrad, K.; Bjornstad, B. ${ }^{10}$ Be dating of late Pleistocene megafloods and Cordilleran Ice Sheet retreat in the northwestern United States. Geology 2017, 45, 583-586. [CrossRef]

11. O'Connor, J.E.; Baker, V.R.; Waitt, R.B.; Smith, L.N.; Cannon, C.M.; George, D.L.; Denlinger, R.P. The Missoula and Bonneville floods-A review of ice-age megafloods in the Columbia River basin. Earth Sci. Rev. 2020, 208. [CrossRef]

12. Atwater, B.F. Status of glacial Lake Columbia during the last floods from glacial Lake Missoula. Quat. Res. 1987, 27, 182-201. [CrossRef]

13. Waitt, R.B. Case for periodic, colossal jökulhlaups from Pleistocene glacial Lake Missoula. Geol. Soc. Am. Bull. 1985, 96, 1271-1286. [CrossRef]

14. Lillquist, K.; Lundblad, S.; Barton, B.R. The Moxee City (Washington) Mammoth: Morphostratigraphic, taphonomic, and taxonomic considerations. West. N. Am. Nat. 2005, 65, 417-428. Available online: https://www.jstor.org/stable/41717478 (accessed on 30 June 2021).

15. Keszthelyi, L.P.; Baker, V.R.; Jaeger, W.L.; Gaylord, D.R.; Bjornstad, B.N.; Greenbaum, N.; Self, S.; Thordarson, T.; Proat, N.; Zreda, M.G. Floods of water and lava in the Columbia River Basin: Analogs for Mars. In The Geological Society of America Field Guide Volcanoes to Vinyards; O'Connor, J.E., Dorsey, R.J., Madin, I.P., Eds.; Geological Society of America: Boulder, CO, USA, 2009; Volume 15, pp. 845-874. [CrossRef]

16. Bjornstad, B.N. Ice-rafted erratics and bergmounds from Pleistocene outburst floods, Rattlesnake Mountain, Washington, USA. EEG Quat. Sci. J. 2014, 63, 44-59. [CrossRef]

17. Last, G.V.; Bjornstad, B.N.; Gessel, B. Distribution of Mammuthus and Erratic Finds Relative to the Size of Ice Age Floods in Southeastern Washington State. In Abstracts with Programs, Proceedings of the GSA Annual Meeeting, Portland, OR, USA, 18-21 October 2009; Geological Society of America: Boulder, CO, USA, 2009; p. 169. Available online: https://gsa.confex.com/gsa/2009 AM/webprogram/Paper162928.html (accessed on 30 June 2021).

18. Smith, G.A. Missoula flood dynamics and magnitudes inferred from sedimentology and slack-water deposits on the Columbia Plateau, Washington. Geol. Soc. Am. Bull. 1993, 105, 77-100. [CrossRef]

19. Bjornstad, B.N. On the Trail of the Ice Age Floods: A Geological Field Guide to the Mid-Columbia Basin; Keokee Books: Sandpoint, ID, USA, 2006; ISBN 978-1-879628-27-4.

20. Barton, B.R. The Moxee-Alexandria mammoth tusk and other mammoth remains from Yakima County, Washington State, USA. In Program and Abstracts, Proceedings of the 3rd International Mammoth Conference, Dawson City, Yukon, 24-29 May 2003; Storer, J.E., Ed.; Yukon Palaeontologist Department of Tourism and Culture Government of Yukon: Whitehorse, YT, Canada, 2003 ; pp. 26-27. Available online: https:/ / emrlibrary.gov.yk.ca/Tourism/international-mammoth-conderence-third-program-abstracts-2003.pdf (accessed on 30 June 2021).

21. Barton, B.R.; Last, G.V. The discovery and distribution of mammoth remains in Benton County, Washington State. In Abstracts with Programs, Proceedings of the Geological Society of America Annual Meeting E Exposition, Denver, CO, USA, 31 October-3 November 2010; Paper No. 19; Geological Society of America: Boulder, CO, USA, 2010; p. 250. Available online: https: //gsa.confex.com/gsa/2010AM/webprogram/Paper179981.html (accessed on 30 June 2021).

22. Barton, B.R.; Last, G.V.; Kleinknecht, G.C. Initial radiocarbon dating of the Coyote Canyon Mammoth, Benton County, Washington State. In Proceedings of the AMQUA 22nd Biennial Meeting, Duluth, MN, USA, 21-24 June 2012; Program and Abstracts, p. 44. 
23. Amara, M.S.; Last, G.V.; Tonnemaker, L.; Tonnemaker, K.; Barton, B.R. Late Pleistocene mammoth remains and their geologic context in the Frenchmand Hills, Grant County, Washington. In Program and Abstracts, Proceedings of the 90th Annual Meeting of the Northwest Scientific Association, Lewiston, ID, USA, 26-29 March 2019; p. 24. Available online: https://www.northwestscience.org/ resources / Documents-Membership-Journal/2019-NWSA-90th-AnnualMeetingProceedings_FINAL_032019_V3.pdf (accessed on 30 June 2021).

24. Last, G.V.; Amara, M.S.; Foit, F.F.; Neill, O.K.; Rittenour, T.; Dodd, J.L.; Tonnemaker, K.; Tonnemaker, L. Tephra and OSL results from the Frenchman Hills-Tonnemaker Mammoth Site, Royal City, Grant County, Washington. In Abstracts with Programs, Proceedings of the GSA Annual Meeting, Seattle, WA, USA, 22-25 October 2017; Geological Society of America: Boulder, CO, USA, 2017; Paper No. 64-7. [CrossRef]

25. Clynne, M.A.; Calvert, A.T.; Wolfe, E.W.; Everts, R.C.; Fleck, R.J.; Lanphere, M.A. The Pleistocene Eruptive History of Mount St. Helens, Washington, from 300,000 to 12,800 Years Before Present. In A Volcano Rrekindled: The Renewed Eruption of Mount St. Helens, 2004-2006; Professsional Paper 1750; Sherrod, D.R., Scott, W.E., Stauffer, P.H., Eds.; U.S. Geological Survey: Boulder, CO, USA, 2008; pp. 593-627. [CrossRef]

26. Guettinger, M.W.; Last, G.V.; Barton, B.R. Geology of the Coyote Canyon Mammoth Site. In Abstracts with Programs, Proceedings of the Geological Society of America Annual Meeting E Exposition, Denver, CO, USA, 31 October-3 November 2010; Paper No. 16; p. 119. Available online: https://gsa.confex.com/gsa/2010AM/webprogram/Paper181951.html (accessed on 30 June 2021).

27. Last, G.V.; Barton, B.R.; Kleinknecht, G.C. Preliminary stratigraphic context of the Coyote Canyon Mammoth Site. In Program and Abstracts, Proceedings of the Northwest Scientific Association Annual Meeting, Boise, ID, USA, 28-31 March 2012; p. 40. Available online: https: / / www.northwestscience.org/Resources/Final\%20Annual\%20Meeting\%20Abstracts\%20and\%20Programs/2012 \%20NWSA \%20Program\%20and\%20Abstracts.pdf (accessed on 30 June 2021).

28. Hill, K.M.; Last, G.V. Lithic analysis of Coyote Canyon Mammoth Site sediments. In Program and Abstracts, Proceedings of the 85th Annual Meeting of the Northwest Scientific Association, Missoula, MT, USA, 26-29 March 2014; p. 66. Available online: https:/ / www.northwestscience.org/Resources/Documents/2014_NWSA-Proceedings_updated-March222014.pdf (accessed on 30 June 2021).

29. Last, G.V.; Krogstad, E.J. The use of X-ray fluorescence spectroscopy to refine stratigraphic interpretation of the Coyote Canyon Mammoth Site. In Program and Abstracts, Proceedings of the 85th Annual Meeting of the Northwest Scientific Association, Missoula, MT, USA, 26-29 March 2014; p. 74. Available online: https:/ / www.northwestscience.org/Resources/Documents/2014_NWSAProceedings_updated-March222014.pdf (accessed on 30 June 2021).

30. Last, G.V.; Barton, B.R.; Kleinknecht, G.C. Working hypotheses from five years of study at the Coyote Canyon Mammoth Site. In Program and Abstracts, Proceedings of the 86th Annual Meeting of the Northwest Scientific Association, Pasco, WA, USA, 1-4 April 2015; p. 67. Available online: https://www.northwestscience.org/resources/Documents/2015\%20Conference/2015-FinalProceedings_ NWSA_Pasco.pdf (accessed on 30 June 2021).

31. Maughan, A.E.; Last, G.V.; Austin, C.J.; Barton, B.R. Lithology and provenance of erratic clasts found at the Coyote Canyon Mammoth Site, Kennewick, Washington. Abstracts with Programs, Cordilleran Sectio. In Proceedings of the 115th Annual Meeting, Portland, OR, USA, 15-17 May 2019. Paper No. 38-3. [CrossRef]

32. Last, G.V.; Maughan, A.E.; Austin, C.J.; Barton, B.R. Ice-rafted erratics from an iceberg feature at the Coyote Canyon Mammoth Site, Kennewick, Washington. In Program and Abstracts, Proceedings of the 90th Annual Meeting of the Northwest Scientific Association, Lewiston, ID, USA, 26-29 March 2019; pp. 45-46. Available online: https:/ / www.northwestscience.org/resources/DocumentsMembership-Journal/2019-NWSA-90th-AnnualMeetingProceedings_FINAL_032019_V3.pdf (accessed on 30 June 2021).

33. Adams, B.L.; Barton, B.R.; Kleinknecht, G.C.; Last, G.V.; Mauldin, B.; Mauldin, K.; Austin, C.J.; Detrick, K.; Mara, N. A late Ice Age camel from the Coyote Canyon/South Hill-Mauldin Site, Benton County, Washington. Abstracts with Programs. In Proceedings of the GSA Annual Meeting, Seattle, WA, USA, 22-25 October 2017. Paper No. 84-32. [CrossRef]

34. Barton, B.R.; Mara, N.; Adams, B.L. Updated chronology of the Camelops hesternus specimen from the Coyote Canyon/South Hill-Mauldin Site, Benton County, Washington. Abstracts with Programs, Cordilleran Section. In Proceedings of the 115th Annual Meeting, Portland, OR, USA, 15-17 May 2019. Paper No. 38-2. [CrossRef]

35. Huntley, D.J.; Godfrey-Smith, D.I.; Thewalt, M.L. Optical dating of sediments. Nature 1985, 313, 105-107. [CrossRef]

36. Aithen, M.J. An Introduction to Optical Dating: The Dating of Quaternary Sediments by the Use of Photon-Stimulated Luminescence; Oxford University Press: Oxford, UK, 1998; ISBN 0198540922.

37. Aitken, M.J.; Xie, J. Moisture correction for annual gamma dose. Anc. TL 1990, 8, 6-9. Available online: http://ancienttl.org/ ATL_08-2_1990/ATL_08-2_Aitken_p6-9.pdf (accessed on 30 June 2021).

38. Guérin, G.; Mercier, N.; Adamiec, G. Dose-rate conversion factor: Update. Anc. TL 2011, 29, 5-8. Available online: https:/ www. aber.ac.uk/en/media/departmental/dges/ancienttl/pdf/vol29no1/atl-issue29-1.pdf\#page=9 (accessed on 30 June 2021).

39. Prescott, J.R.; Hutton, J.T. Cosmic ray contributions to dose rates for luminescence and ESR dating. Radiat. Meas. 1994, 23, 497-500. [CrossRef]

40. Murray, A.S.; Wintle, A.G. Luminescence dating of quartz using an improved single-aliquot regenerative-dose protocol. Radiat. Meas. 2000, 32, 57-73. [CrossRef]

41. Galbraith, R.F.; Roberts, R.G. Statistical aspects of equivalent dose and error calculation and display in OSL dating: An overview and some recommendations. Quat. Geochronol. 2012, 11, 1-27. [CrossRef] 
42. Bergeron, M.P.; Last, G.V.; Reisenauer, A.E. Geohydrology of a Commercial Low-Level Radioactive Waste Disposal Facility Near Richland, Washington; Battelle Pacific Northwest Laboratories: Richland, WA, USA, 1987.

43. Last, G.V.; Bjornstad, B.N.; Busacca, A.J. Influence of Ice Age Floods on the Terroirs of the Yakima Valley Wine Country-A Geologic Field Trip Guide from Richland to Ziillah, Washington; Ice Age Floods Institute, Lake Lewis Chapter: Richland, WA, USA, 2008.

44. Busacca, A.J.; Norman, D.K.; Wolfe, W. Geologic Guide to the Yakima Valley Wine-Growing Region, Benton and Yakima Counties, Washington; Washington State Department of Natural Resources: Olympia, WA, USA, 2008; Available online: https://www.dnr. wa.gov/Publications/ger_ftg2_benton_yakima_wine_region.pdf (accessed on 30 June 2021).

45. Norman, D.K.; Busacca, A.J.; Teissere, R. Geology of the Yakima Valley Wine Country-A Geologic Field Trip Guide from Stevenson to Zillah, Washington; Washington Division of Geology and Earth Resources: Olympia, WA, USA, 2004; Available online: https:/ / dnr.wa.gov / Publications / ger_ftg1_yakima_valley_wine_country.pdf (accessed on 30 June 2021).

46. O'Connor, J.E.; Costa, J.E. The World's Large Floods, Past and Present: Their Causes and Magnitudes; Circular 1254; U.S. Geological Survey: Reston, WV, USA, 2004. [CrossRef]

47. Winseman, J.; Lang, J. Flooding northern germany: Impacts and magnitudes of Middle Pleistocene glacial lake-outburst floods. In Paleohydrology; Herget, J., Fontana, A., Eds.; Springer: Cham, Switzerland, 2020; pp. 29-47. [CrossRef]

48. Mleczak, M.; Pisaraka-Jamrozy, M. A record of deglaciation-related shifting of the proximal zone of a sandur-A case study from the Gwda sandur, NW Poland (MIS 2). J. Palaeogeogr. 2021, 10, 12. [CrossRef] 